\title{
SAUDI ARABIA: A KINGDOM IN PERIL FROM PAUL AARTS AND CAROLIEN ROELANTS
} Augusto Veloso Leão ${ }^{1}$

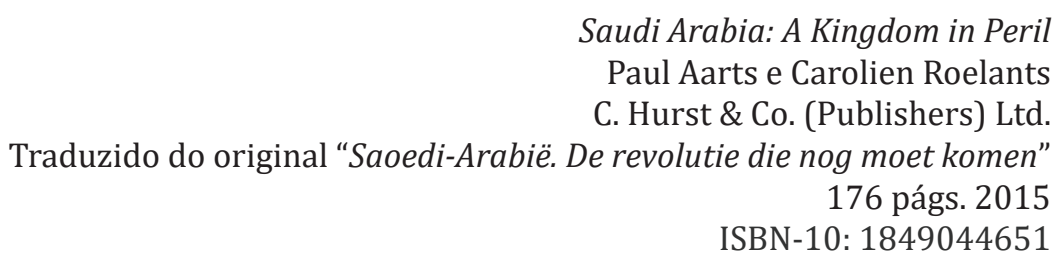

Saudi Arabia: A Kingdom in Peril (Arábia Saudita: Um Reino em Perigo) apresenta um trabalho extenso para capturar as tendências modernizantes em curso na Arábia Saudita e as estratégias da monarquia Al Saud para manter a forte ligação com a corrente islâmica wahhabita. Focando em desafios como a forte dependência econômica da extração do petróleo, os movimentos por autonomia das mulheres e o relacionamento com a corrente xiita do Islã, seguida por uma parte da população da província oriental, Paul Aarts e Carolien Roelants analisam as forças conservadoras e progressistas por detrás das grandes decisões políticas e religiosas contemporâneas no país. Os autores avaliam que a monarquia saudita tem sido extremamente eficiente em utilizar benefícios econômicos e uma bem-alinhada parceria com a liderança religiosa wahhabita para assegurar o controle político e econômico no país, mas que o espaço de manobra tem se tornado cada vez menor por causa da queda de lucratividade da indústria do petróleo e as demandas progressistas de parte de sua população.

As ligações entre a monarquia Al Saud e o wahhabismo datam de 1744, quando seus respectivos fundadores, Muhammad ibn Saud e Muhammad ibn Abd al-Wahhab, celebraram uma aliança político-religiosa que culminou na criação do primeiro estado Saudita. Desde então, a monarquia auxilia na expansão dessa teologia fundamentalista, enquanto recebe o apoio clerical para poder efetivar suas políticas e manter o controle sobre sua população. A partir da fundação do Reino da Arábia Saudita, em 1938, o país viveu um grande crescimento econômico com a descoberta de petróleo em seu território, assim como sofreu um expressivo processo de puritanização e expansão da importância da mutaween, os "voluntários religiosos" sauditas que garantem a aplicação da sharia, especialmente em consequência da ocupação da Grande Mesquita, em Meca, em 1979. Atualmente, a economia baseada no petróleo está em xeque, por causa do aumento do consumo interno para produção de energia e para combustível e a diminuição dos preços internacionais do produto. A família real detém e gasta uma parte considerável das receitas

\footnotetext{
${ }^{1}$ Mestre e doutorando em Relações Internacionais pela Universidade de São Paulo.
} 
do petróleo e utiliza uma outra parte para oferecer subsídios e benefícios para a população, mantendo o preço do combustível e energia artificialmente baixos ou oferecendo proteção no desemprego, por exemplo. Aarts e Roelants afirmam que a partir de 2015, utilizando dados do Institute for International Finance e do Deutsche Bank, a Arábia Saudita teria grandes déficits públicos (p.26) - efetivamente, o deficit para o ano de 2015 foi calculado em torno de 100 bilhões de dólares ${ }^{2}$. Por outro lado, a teologia wahhabita e seus principais líderes têm sofrido perdas de credibilidade por causa da utilização do wahhabismo como fonte de inspiração para movimentos extremistas e terroristas islâmicos e das críticas sobre a forte repressão e controle, especialmente sobre as mulheres sauditas e sobre os dissidentes religiosos.

É neste pano de fundo que o livro apresenta a situação na Arábia Saudita, principalmente a partir dos diferentes desafios modernizantes contemporâneos em cada capítulo: as ambições por emprego e modernização cultural das novas gerações sauditas; as demandas por autonomia das mulheres; as mudanças no sistema educacional; as novas formas de interação e contatos com outras culturas trazidas pela internet e as mídias sociais; o reflorescimento da arte no país, a questão da minoria xiita; e a influência dos movimentos revolucionários da Primavera Árabe.

Com quase dois terços da população com menos de trinta anos de idade, a Arábia Saudita está atualmente experimentando uma chegada maciça de pessoas ao mercado de trabalho para os quais não haverá emprego ou que terão que se empregar em atividades que requerem menos qualificações do que aquelas que possuem. Esta população está também acostumada a viver as benesses de uma economia em expansão e com os benefícios que são oferecidos pelo governo, que provavelmente diminuirão frente à perspectiva de deficit. Além disso, pesa o fato de a segregação entre os sexos e a forte repressão religiosa encontrar relativa resistência entre parcelas das gerações mais jovens. As mulheres sauditas, que vivem com pouca autonomia e necessitam da aprovação de responsáveis homens para determinadas escolhas, como trabalhar fora, também começam a apresentar suas demandas no espaço público com mais determinação, por exemplo, com relação à proibição de dirigir carros.

O sistema educacional, que esteve sempre sob o controle direto dos líderes religiosos, passou por revisões importantes depois que a participação saudita e de fundamentos religiosos wahhabitas foram utilizados por movimentos extremistas e ataques terroristas no mundo e dentro do próprio país. Como consequência do aumento do contato que os sauditas têm com outras culturas, através de bolsas de estudo no exterior ou da internet, o sistema escolar também passou a incluir uma preocupação de possibilitar a reflexão autônoma dos alunos e ir além da mera repetição de conteúdos. Os sauditas têm uma das maiores taxas de acesso e utilização de internet do Oriente Médio e isso já tem reflexos

\footnotetext{
2 "Saudi Arabia launches austerity drive to cut public spending" (Arábia Saudita lança medidas de austeridade para cortar os gastos públicos). The Guardian, 14 de Março de 2016. (https://www.theguardian.com/ world/2016/mar/14/saudi-arabia-launches-austerity-drive-cut-public-spending)
} 
em suas formas de expressão e na possibilidade de criar ou entrar em contato com visões críticas sobre o país e seus sistema político e religioso. A expressão artística, proibida pela teologia wahhabita como pecado e como forma de idolatria, também vive uma forma de renascimento, ainda tímido, e encontra novos espaços, como o cinema e a produção audiovisual, ou as performances públicas, além da já mencionada internet.

Outro desafio é a forma de relacionamento com a minoria xiita, presente na província oriental saudita. Com a reforma do material escolar, parte dos ensinamentos que exacerbavam que o xiismo era uma forma ilegítima do Islã foram revisados, mas essa população ainda reclama de discriminação e de violência. 0 relacionamento antagônico com o Irã agrava a situação dos xiitas sauditas, especialmente com a partir do desenvolvimento da guerra na Síria: os dois países apoiam lados diferentes do conflito. A guerra civil na Síria, assim como o golpe no Egito, e a escalada da situação na Líbia são interpretados pela sociedade saudita de maneira contraditória. Se bem mostraram a possibilidade da demanda popular por reformas democratizantes e modernizantes, também serviram para que os sauditas se tornassem cautelosos frente às possibilidades de conflito e empobrecimento geral.

É importante notar que, apesar do foco maior do livro nas pressões modernizantes na Arábia Saudita, os autores também apresentam os diversos movimentos contrários e tradicionalistas que ganham força a cada demanda por mudança e a cada modificação para suavizar o controle religioso. É de se esperar, inclusive, que estes movimentos sejam mais fortes do que são descritos no livro, que, apesar de grande esforço, não escapa a uma visão ocidentalizada sobre a situação no país, oferecendo aos movimentos modernizadores uma ótica positiva quase automática, ao mesmo tempo que oferece uma visão crítica a todos os movimentos contrários.

Por fim, Aarts e Roelants terminam como uma reflexão sobre o futuro da monarquia saudita, analisando diferentes cenários e calculando as possibilidades de manutenção da monarquia frente a esses desafios. Uma das conclusões mais impactantes é a de que as reformas promovidas pela monarquia poderem representar um caminho sem volta. Retomando o conceito de Samuel Huntington, o "dilema do rei" sugere que monarcas que promovem reformas no sistema político dão impulso a uma dinâmica de mudança que depois acarretam a derrocada do sistema absolutista. Dessa maneira, como os autores reforçam enfaticamente: "a monarquia saudita se sente sitiada", ainda que as forças contestatórias ainda não representem um perigo real. Para Aarts e Roelants, a forma como a Arábia Saudita reagiu à ascensão e à queda da Irmandade Muçulmana no Egito, tem repreendido os militantes que atuam no conflito sírio, e endureceram o cerco aos defensores dos direitos humanos mostram a preocupação em não dar espaço para movimentos que possam fortalecer as críticas à monarquia.

Levando o título ao pé da letra, é intrigante que a Arábia Saudita descrita por Aarts e Roelants não passa perto de estar em perigo, especialmente em comparação com os 
demais sistemas políticos na região. É possível que a Arábia Saudita seja, neste momento, um dos sistemas mais estáveis e que conta com o maior apoio popular no Oriente Médio. Mas os autores são enfáticos em sua descrição e são muito bem sucedidos em demonstrar as situações de potencial para crise que o país enfrenta atualmente e como o arranjo entre a monarquia Al Saud e a teologia wahhabita vive uma situação de fragilidade, mesmo com as recentes expressões de força, como a decapitação de 47 prisioneiros em Janeiro de 2016, incluindo o líder xiita Sheikh Nimr al-Nimr. Na Arábia Saudita, o perigo pode já estar à espreita, resta saber qual a forma exata que ele vai tomar e quais serão as consequências para o país e sua população. 